\title{
PERFORMANCE OF MULTI STORIED BUILDING FOR VARIOUS LOCATIONS OF SHEAR WALL
}

\author{
Ms. Medini Deshpande ${ }^{1}$, Dr. M.G.Kalyanshetti ${ }^{2}$ and Dr. S.A.Halkude ${ }^{3}$
}

\begin{abstract}
Earthquakes are natural hazards under which disasters are mainly caused by devastating damage due to sudden collapse of buildings mainly occurring due to dynamic actions. A systematic investigation has shown that shear wall structures have performed remarkably well in the most severe earthquakes around the world. Location of the shear wall plays an important role in multistoried building. Therefore, in the present work parametric study has been carried out to study the seismic parameters like roof displacement, storey drift and time period by providing shear walls at various locations in a building frame by changing percentage length of shear walls and by changing number of stories. The study shows that when shear walls are placed equally in both $\mathbf{X} \&$ in $\mathbf{Y}$-direction, seismic performance is observed to be better than shear walls placed in either $\mathrm{X}$ or Y-direction individually. When shear walls are provided in only one direction, structure resist lateral forces in that direction only. Therefore, geometry of the shear wall in both directions should be maintained. However, present study reveals that in view of overall stability shear walls are recommended in X \& Y-directions symmetrically placed in both directions (50-50\%).

Keywords- Shear wall, Earthquake, earthquake load resisting system, Response spectrum analysis method, roof displacement, storey drift, time period.
\end{abstract}

\section{INTRODUCTION}

There has been a considerable increase in the construction of tall buildings. Today's buildings are becoming more and more slender, leading to the possibility of more sway. Therefore the impact of seismic forces acting on them becomes an important aspect of the design.

Improving the structural systems of tall buildings can control their dynamic response. With more appropriate structural forms such as RC shear walls, and improved material properties, the maximum height of concrete buildings has soared in recent decades. Performance of structures under frequently occurring earth quake ground motions resulting in structural damages. Similarly, failures have repeatedly demonstrated the seismic vulnerability of existing buildings, due to their conventional design based on gravity loads only. This necessitates the need for design based on seismic responses by suitable methods to ensure strength and stability of structures.

Shear wall systems are one of the most commonly used lateral load resisting systems in high rise buildings. Some of The advantages of shear walls are- they are very rigid in their own plane and hence are effective in controlling deflections. They act as fire compartment walls. Shear walls are efficient in both in terms of construction cost and effectiveness in minimizing earthquake damage in structural and nonstructural elements. When shear wall are situated in advantageous positions, they can form an efficient lateral force resisting system.

The effort has been made to study the behavior of RC shear wall in the RC frame at various locations by changing their orientation and by increasing the percentage length in plan configuration. Comparison of the results in both $\mathrm{X}$ $\&$ Y-directions has to be done and to identify which case will provide optimum results for the structure. Different number of stories i.e. 10, 14, 18 and 22 are considered for analysis by considering different seismic parameters such as roof displacement, storey drift and time period.

\footnotetext{
${ }^{1}$ P.G.Studant, Department of Civil Engineering, Walchand Institute of Technology, Solapur, Maharashtra, India

${ }^{2}$ Associate Professor, Department of Civil Engineering Walchand Institute of Technology, Solapur, Maharashtra, India

${ }^{3}$ Principal Walchand Institute of Technology, Solapur, Maharashtra, India
} 


\section{RELATED WORK}

Many researchers have studied the performance of high rise buildings using shear walls, compared the seismic parameters and determined best suitable location of shear wall in building frame.

P. P. Chandurkar et.al ${ }^{(12)}$ (2013) studied for best shear wall location in multi-storey building. One model for bare frame type and three models for dual type structural system were considered and revealed that shear wall in short span at corner was economical. Large dimension of shear wall is not effective in 10 stories or below 10 stories buildings. Providing shear walls at adequate locations substantially reduces the displacements due to earthquake.

Lakshmi K.O.et. al. ${ }^{(8)}$ (2014) has compared parameters such as storey drift, storey shear, deflection under lateral loads based on strategic positioning of shear walls. it is observed that response spectrum analysis results provides a more realistic behavior of structure response and hence it can be seen that the displacement values in both $\mathrm{X}$ and $\mathrm{Y}$ directions are least in model with shear wall in core and corners.

R.S.Mishra et. al. ${ }^{(13)}$ (2015) propose the seismic behavior of the building consists of 11 floors. Analysis based on designed structure with various positional configuration of shear wall with respect to seismic load shows that, Intermediate position of shear wall is best suited with respect to core and periphery positions of the structure.

Dr. Halkude S.A. et.al ${ }^{(4)}$ (2015) Determined the best location of shear wall in multi-storey reinforced concrete framed buildings of different heights with shear wall at five alternate locations in the building incorporating the effect of soil flexibility and revealed that, shear walls play important role to control SSI effect and very effective when placed centrally, near to centroid of building in resisting seismic load

P. Mary Williams ${ }^{(11)}$ et.al (2016) discussed the effect of shear wall and its location on the linear and nonlinear behavior of irregular buildings with different eccentricities. it is observed that shear wall on the outer edges is more advisable to improve the behavior of asymmetric buildings. A building with shear wall shows more plastic behavior in the middle stories. When shear wall is provided at the core as a box, the displacement, drift and torsion reduces by a larger value.

Well-designed shear walls not only provide adequate safety, but also give a great measure of protection against costly non-structural damage during moderate seismic disturbances. Literature survey has been made to know the optimum location of shear walls in a building structure and according to that parametric study has been done on location and orientation of shear walls by changing percentage length and by considering different number of stories.

\section{MODELING AND ANALYSIS OF STRUCTURE}

In the present study residential building is considered which is located in zone III having length of the building is 20 $\mathrm{m}$ and breadth of the building is $22 \mathrm{~m}$. from length and breadth of the building $\mathrm{L} / \mathrm{b}$ ratio is 1.1 . The building with different percentage length of shear wall used in one or both directions is analyzed using software ETABS. Different number of storey is also considered for the study.

A 3-dimentional model of the building is created by ETABS. The shear walls are represented by rectangular plate elements. The study has been done to obtain the best location of shear wall in plan configuration of the building as well as to find out suitable percentage length of shear walls placed along either direction. Figure 3.1 shows building plan and column positions of structure and its elevation which is considered for parametric study. 


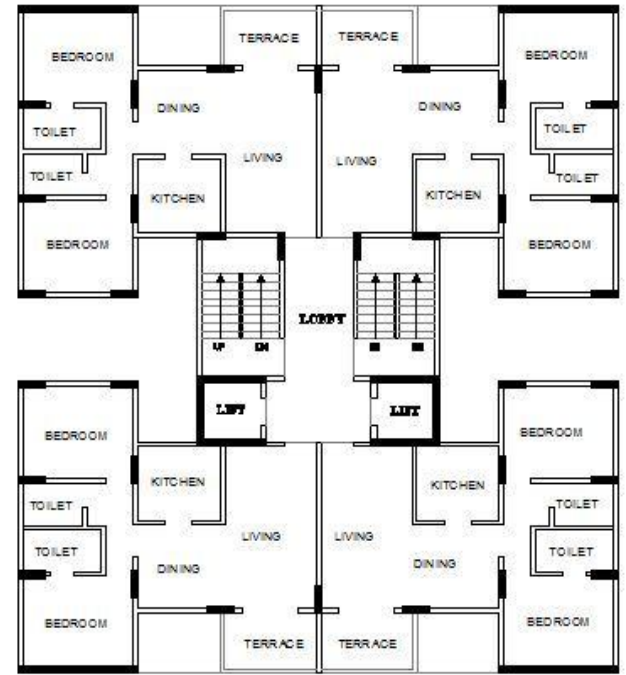

(a)

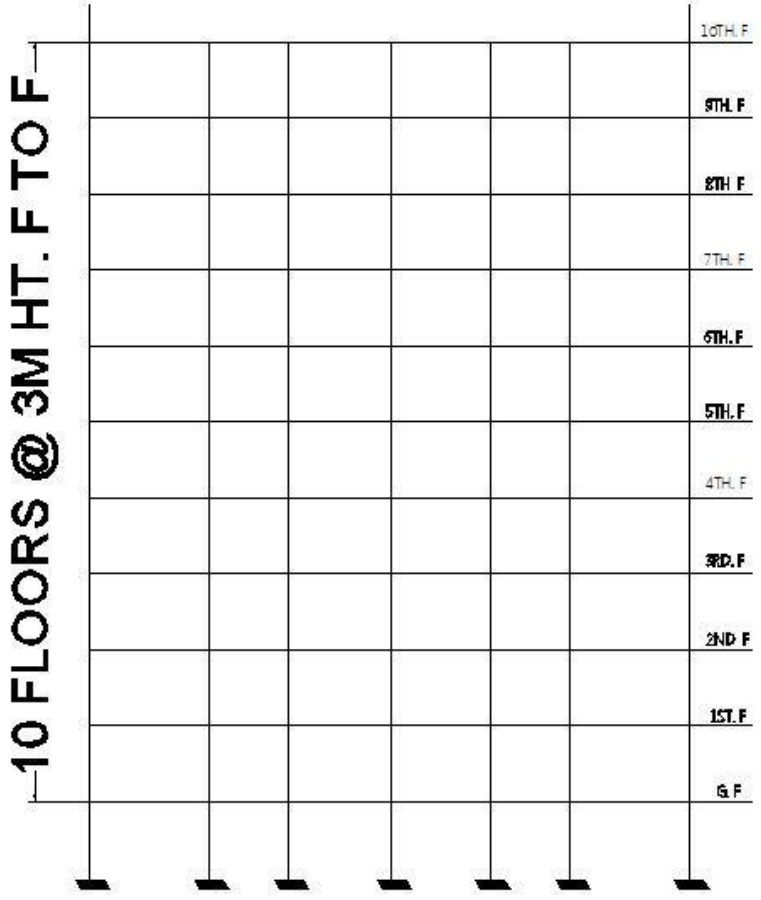

(b)

Figure no. 3.1 (a) Column Positions of Structure, (b) Elevation

3.1 Data considered for analysis-

The general information of the building is as below

1. Zone : III

3. Response reduction factor : 5

5. Column size $\quad: 230 \times 900 \mathrm{~mm}$

2. Importance factor $\quad: 1$

4. Soil condition : medium (type II)

7. Slab thickness $\quad: 125 \mathrm{~mm}$

9. Grade of concrete : M30

6. Beam size

: $230 \times 600 \mathrm{~mm}$

8. RC wall thickness $\quad: 230 \mathrm{~mm}$

10. Grade of Steel : Fe 500

Loads on the structure is self weight of the structure and live load of $2 \mathrm{kN} / \mathrm{m}^{2}$ considered for analysis. Full dead load (self weight) and $25 \%$ of live (Imposed) load constitute the seismic weight. Load combinations considered for analysis are:
1. $1.5(\mathrm{DL}+\mathrm{LL})$
2. $1.2(\mathrm{DL}+\mathrm{LL} \pm \mathrm{EQ})$
3. 1.5(DL $\pm E Q)$

\subsection{Cases considered for study-}

The models are arranged in various groups according to percentage of shear walls. With each percentage of shear walls there are three models.

$\mathrm{M} 1=$ shear walls placed symmetrically only in X-direction

M2= shear walls placed symmetrically only in Y-direction

M3= shear walls placed equally in both X \& Y-direction

Considering shear walls for lift pit as a constant for all the cases i.e. (keeping $7 \%$ of shear walls constant) number of shear walls has been changed from 4 to 12 with interval of two. Table 3.1 shows three cases which are considered depending upon location and percentage of shear walls.

Table no. 3.1 Cases considered for study

\begin{tabular}{|c|c|c|c|c|}
\hline Sr. No. & No. of Story & No. of Cases & No. of Shear wall & \% of Shear wall \\
\hline \multirow{3}{*}{1} & \multirow{3}{*}{10} & \multirow{3}{*}{ M1 to M3 } & 4 & 12.5 \\
\cline { 4 - 5 } & & & 6 & 19 \\
\cline { 4 - 5 } & & & 10 & 25 \\
\cline { 4 - 5 } & & & 12 & 31 \\
\hline
\end{tabular}


3.3Various models considered-

In this present study following types of models are generated and analyzed for seismic load as shown in table no.3.2.

Table no. 3.2 Models with different number and location of shear walls

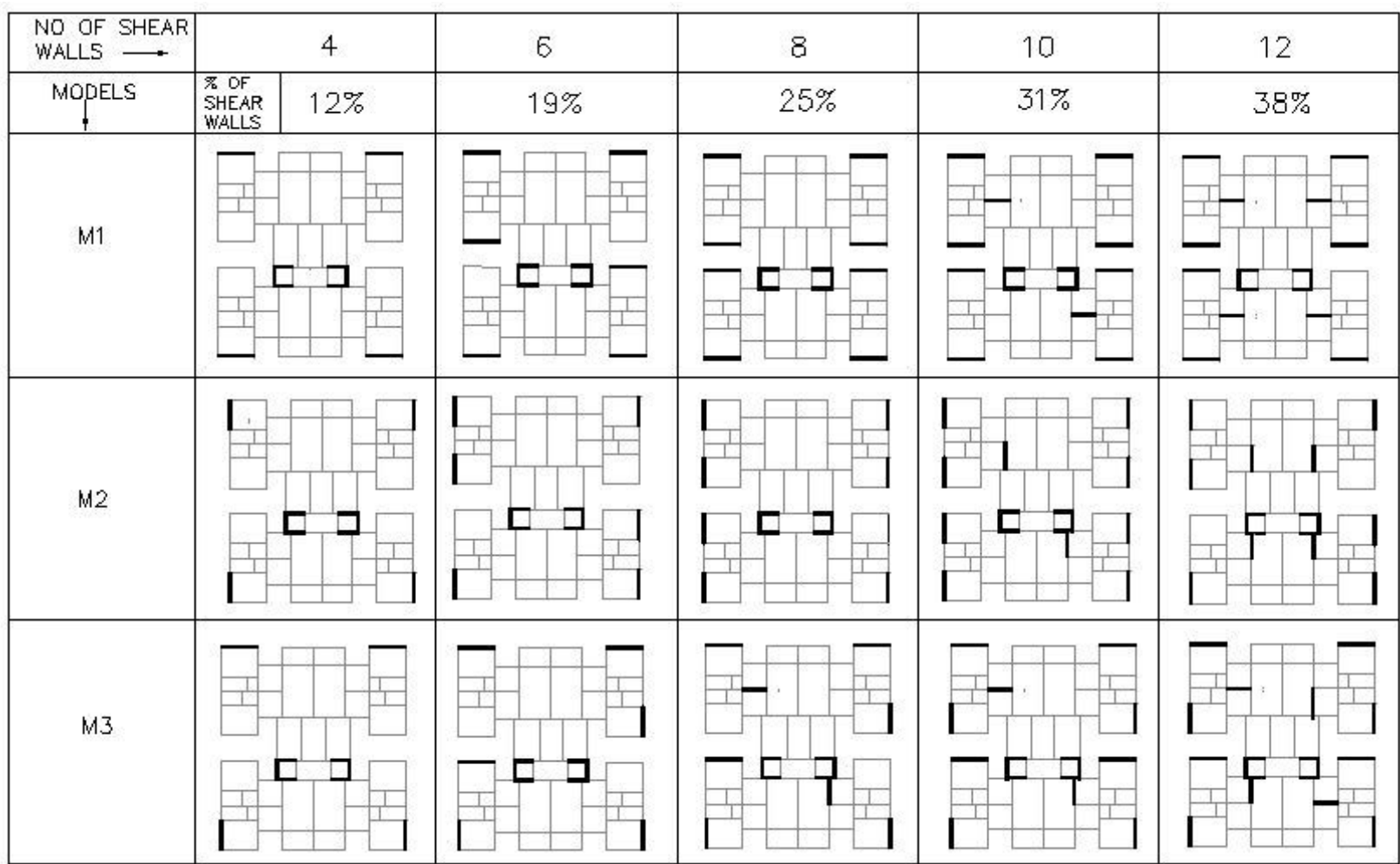

\section{RESULTS AND DISCUSSION}

Analysis of the structure has been done on ETAB using response spectrum method and from the results following graph have been plotted to study variation of seismic parameters i.e. roof displacement, storey drift and time period along the both directions.

4.1 10-storey building frame-

1) Roof Displacement-

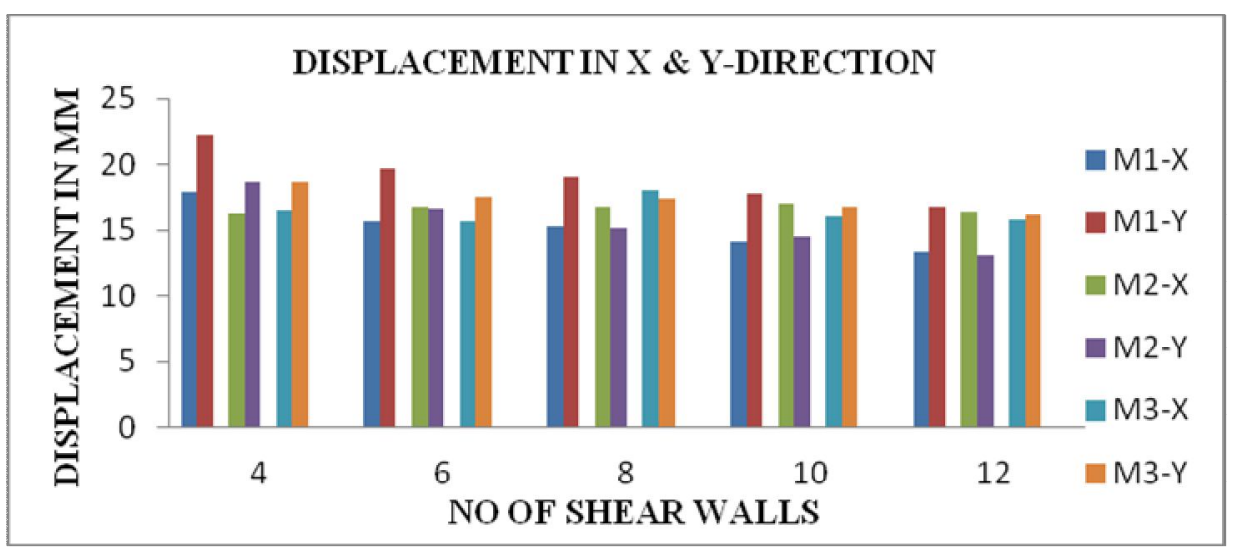

Figure 4.1 Roof Displacement (in $\mathrm{mm}$ ) in X \& Y-direction for 10 storey building frame

Figure 4.1 shows variation of displacement in $\mathrm{X} \& \mathrm{Y}$-direction for the various combinations of orientation in $\mathrm{X} \& \mathrm{Y}$-direction for given number of shear walls varying from 4 to 12. 
When all shear walls placed in X-direction (case M1), displacement in X-direction is less in comparison with Y-direction. This is observed for all number of shear walls. As such in comparison displacement decreases by $12 \%$ from 4 to 6 number of shear walls, $3 \%$ from 6 to 8 number of shear walls, $7 \%$ from 8 to 10 number of shear walls and $6 \%$ from 10 to 12 number of shear walls. Overall displacement in X \& Y-direction reduces by almost $25 \%$ from 4 to 12 number of shear walls.

When all shear walls placed in Y-direction (caseM2), initially for 4 number of shear walls, displacement is less in X-direction in comparison with displacement in Y-direction. However, for 6 number of shear walls, displacement in $\mathrm{X}$-direction is slightly greater than displacement in Y-direction. However, it is observed that with increasing shear wall, displacement in X-direction increases at a milder rate. With increase in number of shear walls the difference between displacements in $\mathrm{X} \& \mathrm{Y}$-direction keeps on increasing. In X-direction displacement decreases by 5\% and in Y-direction displacement decreases by almost 30\% from 4 to 12 numbers of shear walls.

For shear walls equally placed in both directions (caseM3), initially for $4 \& 6$ number of shear walls, displacement in X-direction is lower in comparison with Y-direction. However, with increase in number of shear walls displacement in X-direction is increases and displacement in Y-direction decreases. For 8 number of shear walls, displacement in $\mathrm{X}$-direction is higher than that of $\mathrm{Y}$-direction. For $10 \& 12$ number of shear walls, overall displacement is getting reduced. However, displacement in X-direction is found to be decreased than displacement in Y-direction. Obviously with increase in number of shear walls displacement in either direction is observed to be decreases.

Among all the cases, roof displacement in both $\mathrm{X} \& \mathrm{Y}$-direction is observed to be less in comparison with M1 \& M2 and equal in both directions when shear walls are placed equally in both X \& Y-direction (case M3). Therefore it is revealed that provision of shear walls along both X \& Y-direction is beneficial as that of shear walls providing individually in $\mathrm{X}$ or $\mathrm{Y}$-direction.

From 4 to 8 number of shear walls, rate of decrease in displacement is steeper. However, for $10 \& 12$ number of shear walls, rate of decrease in displacement is milder and negligible. Therefore, provision of 4 to 8 numbers of shear walls gives better performance and further increase in the shear wall is observed to be not effective.

2) Storey Drift-

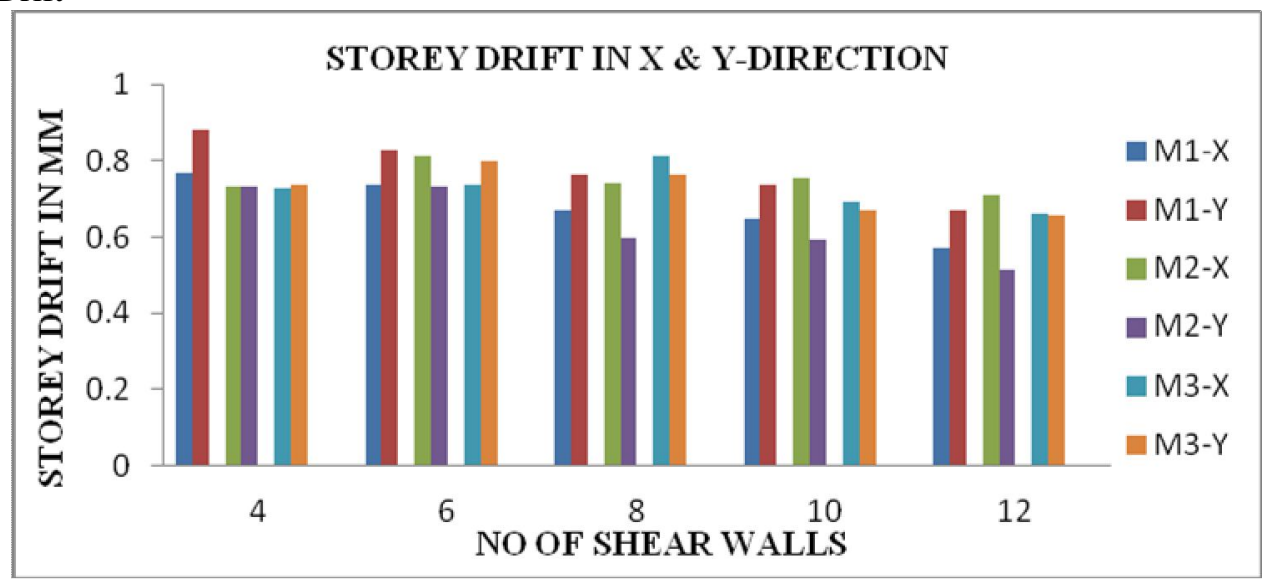

Figure 4.2 Storey Drift (in mm) in X \& Y-direction for 10 storey building frame

Figure 4.2 shows variation of drift in $\mathrm{X} \& \mathrm{Y}$-direction for the various combinations of orientation in $\mathrm{X} \&$ $\mathrm{Y}$-direction for given number of shear walls varying from 4 to 12.

When all shear walls placed in X-direction (case M1), drift in X-direction is less in comparison with Ydirection. It is observed for all number of shear walls. Storey drift in X-direction decreases by $4 \%$ from 4 to 6 numbers of shear walls, $9 \%$ from 6 to 8 numbers of shear walls, $3 \%$ from 8 to 10 number of shear walls and $12 \%$ from 10 to 12 number of shear walls. Overall drift in $\mathrm{X}$-direction reduces by almost $25 \%$ \& in $\mathrm{Y}$ direction drift reduces by almost $23 \%$ from 4 to 12 number of shear walls.

When all shear walls placed in Y-direction (caseM2), initially for 4 number of shear walls, drift in Xdirection is nearly same with drift in Y-direction. With increase in number of shear walls the difference between drift in X \& Y-direction keeps on increasing. With increasing shear wall, the drift in X-direction decreases upto $12 \%$ and in Y-direction drift decreases by almost upto $30 \%$ from 4 to 12 numbers of shear walls. 
For shear walls equally placed in both directions (caseM3), initially for 4 number of shear walls, drift in Xdirection is slightly less in comparison with Y-direction. However, with increase in number of shear walls drift in Xdirection increases and drift in Y-direction decreases. For 8 number of shear walls, drift in X-direction is higher than that of Y-direction. For $10 \& 12$ number of shear walls, even though overall drift is getting reduced in either direction. However, drift in X-direction is still found to be slightly higher than drift in Y-direction. Obviously with increase in number of shear walls drift in either direction is observed to be decreasing.

Among all the cases, storey drift in both X \& Y-direction is observed to be less in comparison with M1 \& M2 when shear walls are placed in both X \& Y-direction (case M3). Therefore it is revealed that provision of shear walls along both $\mathrm{X} \&$ Y-direction is beneficial.

From 4 to 8 number of shear walls, rate of decrease in drift is steeper. However, from $10 \& 12$ number of shear walls rate of decrease in drift is milder and negligible. Therefore, provision of 4 to 8 numbers of shear walls gives better performance and further increase in the shear wall is observed to be not effective.

3) Time period-

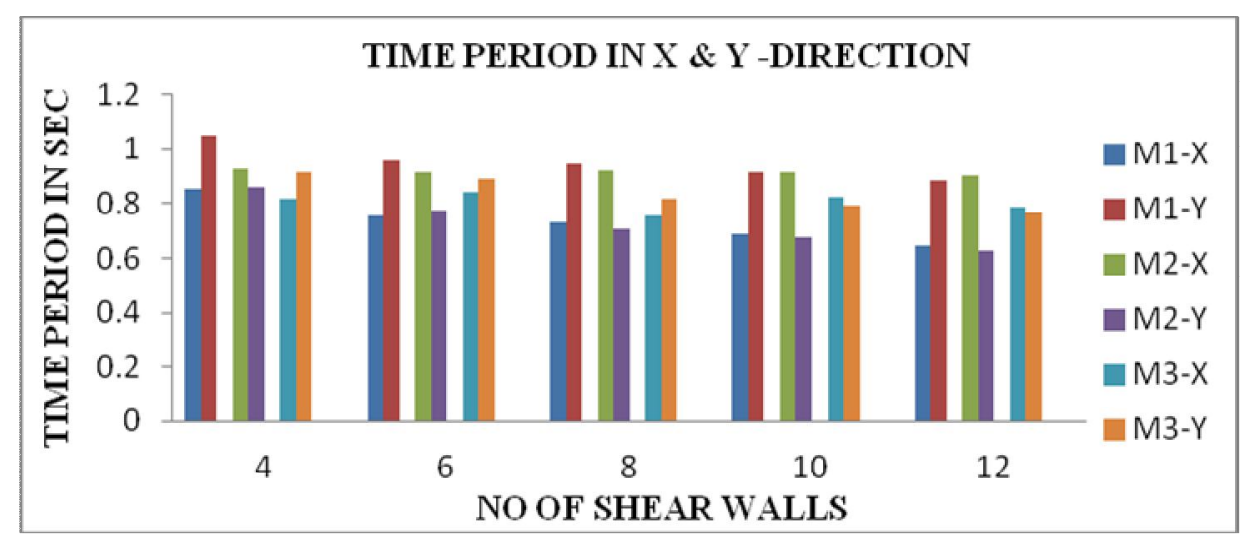

Figure 4.3 Time period (in sec) in X \& Y-direction for 10 storey building frame

Figure 4.3 shows variation of time period in $\mathrm{X} \& \mathrm{Y}$-direction for the various combinations of orientation in $\mathrm{X} \& \mathrm{Y}$-direction for given number of shear walls varying from 4 to 12 .

When all shear walls placed in X-direction (case M1), time period in X-direction is less in comparison with Y-direction. it is observed for all number of shear walls. time period in X-direction decreases by $12 \%$ from 4 to 6 numbers of shear walls, 3\% from 6 to 8 numbers of shear walls, $5 \%$ from 8 to 10 number for shear walls and $6 \%$ from 10 to 12 number of shear walls. Overall time period in X -direction reduces by almost $24 \%$ \& in Y direction time period reduces by almost $16 \%$ from 4 to 12 number of shear walls.

When all shear walls placed in Y-direction (caseM2), initially for 4 number of shear walls, time period in $\mathrm{X}$-direction is slightly higher than time period in Y-direction. With increase in number of shear walls the difference between time periods in X \& Y-direction keeps on increasing. In X-direction time period decreases by $3 \%$ and in $\mathrm{Y}$ direction time period decreases by almost $27 \%$ from 4 to 12 numbers of shear walls.

For shear walls equally placed in both directions (caseM3), for $4 \& 6$ number of shear walls time period in $\mathrm{X}$-direction is less in comparison with Y-direction. However, with increase in number of shear walls time period in $\mathrm{X}$-direction increases and time period in Y-direction decreases. For 8 number of shear walls, time period in $\mathrm{X}$ direction is less than Y-direction. For $10 \& 12$ number of shear walls, overall time period is getting reduced. However, time period in X-direction is found to be slightly greater than time period in Y-direction. Obviously with increase in number of shear walls time period in either direction is observed to be decreases.

Among all the cases, time period in both X \& Y-direction is observed to be less when shear walls are placed in both X \& Y-direction (case M3). Therefore it is revealed that provision of shear walls along both X \& Ydirection is beneficial.

From 4 to 8 number of shear walls, rate of decrease in time period is steeper. However, from $10 \& 12$ number of shear walls rate of decrease in time period is milder and negligible. Therefore, provision of 4 to 8 numbers of shear walls gives better performance and further increase in the shear wall is not observed to be effective.

4.2 Variation of seismic parameters with increasing number of storey- 
10 storey building is considered for parametric study of building frame with different percentage length of shear walls at different locations and its orientations in one or both directions as discussed in section no.4.1. From the study of 10 storey building it is observed that, when shear walls are equally spaced in both the directions i.e. M3 combination, the seismic performance of the building is found to be best one.

Therefore, for the studying the effect of increasing storey, considering M3 combination for 14, 18, 22 storey building with same plan and similar \% shear wall. Therefore, placing shear walls equally in both X \& Ydirection (case M3), parametric study is carried out on various seismic parameters influencing seismic behavior of the structure. The various combinations of shear walls along both $\mathrm{X} \& \mathrm{Y}$-directions for all the building frames are tabulated in Table no.4.1.

Table no.4.1 Seismic parameters with different no. of storey and different no. of shear walls

\begin{tabular}{|c|c|c|c|c|c|c|c|c|c|c|c|c|}
\hline & \multicolumn{4}{|c|}{ DISPLACEMENT $(\mathrm{mm})$} & \multicolumn{4}{|c|}{ DRIFT $(\mathrm{mm})$} & \multicolumn{4}{|c|}{ TIME PERIOD $(\mathrm{sec})$} \\
\hline $\begin{array}{c}\text { No of } \\
\text { Shear } \\
\text { Walls } \downarrow\end{array}$ & 10 & 14 & 18 & 22 & 10 & 14 & 18 & 22 & 10 & 14 & 18 & 22 \\
\hline 4 -along $X$ & 16.6 & 24.3 & 32.8 & 42 & 0.73 & 0.75 & 0.77 & 0.8 & 0.82 & 1.24 & 1.69 & 2.2 \\
\hline 4-along Y & 18.7 & 29.8 & 43.8 & 59.3 & 0.74 & 0.86 & 0.97 & 1.08 & 0.91 & 1.38 & 1.89 & 2.44 \\
\hline 6 -along $\mathrm{X}$ & 15.6 & 24.3 & 32.8 & 41.8 & 0.74 & 0.85 & 0.93 & 1.01 & 0.84 & 1.21 & 1.65 & 2.11 \\
\hline 6-along Y & 17.5 & 28.4 & 42.3 & 58 & 0.8 & 0.96 & 1.14 & 1.3 & 0.89 & 1.34 & 1.84 & 2.4 \\
\hline 8 -along $X$ & 18.1 & 22.9 & 30.6 & 41.7 & 0.81 & 0.82 & 0.88 & 1.01 & 0.76 & 1.22 & 1.68 & 2 \\
\hline 8-along Y & 17.4 & 28 & 41.3 & 57.8 & 0.77 & 0.96 & 1.11 & 1.29 & 0.82 & 1.22 & 1.74 & 2.24 \\
\hline 10 -along X & 16.1 & 22 & 30 & 38.8 & 0.69 & 0.71 & 0.75 & 0.78 & 0.83 & 1.21 & 1.63 & 2.1 \\
\hline 10-along Y & 16.8 & 26.7 & 40.5 & 51.1 & 0.67 & 0.78 & 0.91 & 1.05 & 0.79 & 1.18 & 1.66 & 2.16 \\
\hline 12 -along X & 15.8 & 22.5 & 30.2 & 38.7 & 0.67 & 0.72 & 0.75 & 0.77 & 0.79 & 1.1 & 1.5 & 1.93 \\
\hline 12-along Y & 16.2 & 24.6 & 36.6 & 51.1 & 0.67 & 0.78 & 0.91 & 1.05 & 0.77 & 1.11 & 1.58 & 2.05 \\
\hline
\end{tabular}

The variations of individual parameters such as displacement, drift and time period are shown below in Figure 4.4, $4.5,4.6$ respectively.

1) Roof Displacement:

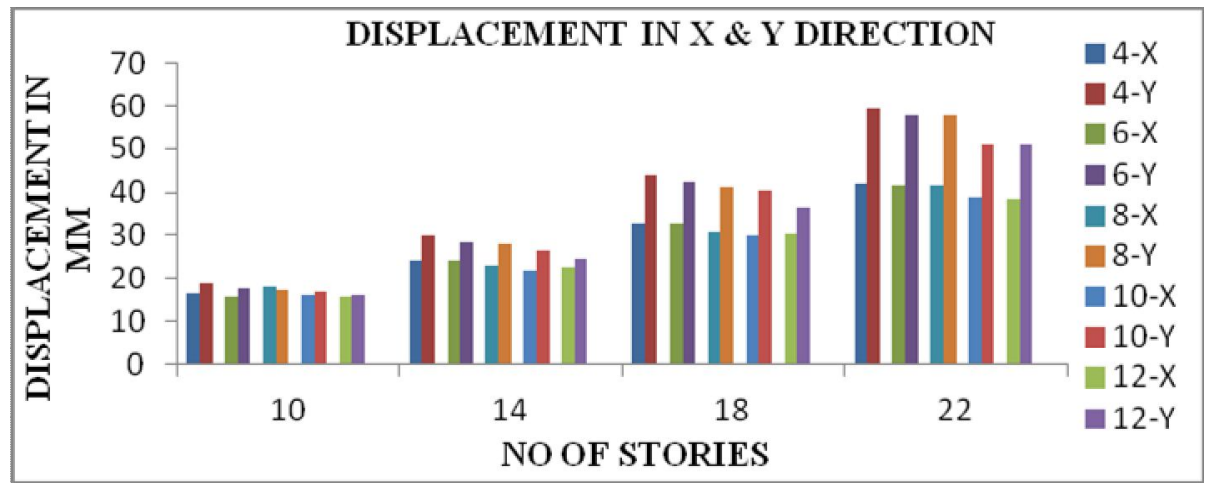

Figure 4.4 Roof Displacement (in mm) in X \& Y-direction

Figure 4.4 shows variations in displacement in both X \& Y-direction for case M3 for given number of shear walls (varying from 4 to 12 numbers) and for various stories $10,14,18 \& 22$. The detailed discussion for 10 storeys is already presented.

For M3 combination with increasing no of shear walls, it is observed that minimum displacement in $\mathrm{X}$ direction is $15.6 \mathrm{~mm}$ for 10 storey building which increases to $22 \mathrm{~mm}$ for 14 storey building ( $29 \%$ increase w.r.t. 10 storey building). Further for 18 storey building displacement is increased to $30 \mathrm{~mm}$ ( $27 \%$ increase w.r.t. 14 storey building) and then after increases to $38.7 \mathrm{~mm}$ for 22 storey building ( $22 \%$ increase w.r.t. 18 storey building). Overall, from 10 to 22 storey building the minimum displacement in X-direction has increased from $15.6 \mathrm{~mm}$ to $38.7 \mathrm{~mm}$ (60\% increases from 10 to 22 storey building). 
The minimum displacement in $\mathrm{Y}$ direction with increasing no of shear walls is observed to be $16.2 \mathrm{~mm}$ for 10 storey building which increases to $24.6 \mathrm{~mm}$ for 14 storey building (34\% increase w.r.t. 10 storey building). Further for 18 storey building displacement is increased to $36.6 \mathrm{~mm}$ (33\% increase w.r.t. 14 storey building) and then after increases to $51.1 \mathrm{~mm}$ for 22 storey building ( $28 \%$ increase w.r.t. 18 storey building). Overall, from 10 to 22 storey building the minimum displacement in Y-direction has increased from $16.2 \mathrm{~mm}$ to $51.1 \mathrm{~mm}(68 \%$ increases from 10 to 22 storey building).

The maximum displacement in $\mathrm{X}$ direction with increasing no of shear walls is observed to be $18.1 \mathrm{~mm}$ for 10 storey building which increases to $24.3 \mathrm{~mm}$ for 14 storey building (25\% increase w.r.t. 10 storey building). Further for 18 storey building displacement is increased to $32.8 \mathrm{~mm}$ ( $26 \%$ increase w.r.t. 14 storey building) and then after increases to $42 \mathrm{~mm}$ for 22 storey building ( $22 \%$ increase w.r.t. 18 storey building). Overall, from 10 to 22 storey building the maximum displacement in X-direction has increased from $18.1 \mathrm{~mm}$ to $42 \mathrm{~mm}$ (57\% increases from 10 to 22 storey building).

The maximum displacement in $\mathrm{Y}$ direction with increasing no of shear walls is observed to be $18.7 \mathrm{~mm}$ for 10 storey building which increases to $29.8 \mathrm{~mm}$ for 14 storey building (37\% increase w.r.t. 10 storey building). Further for 18 storey building displacement is increased to $43.8 \mathrm{~mm}$ ( $32 \%$ increase w.r.t. 14 storey building) and then after increases to $59.3 \mathrm{~mm}$ for 22 storey building ( $26 \%$ increase w.r.t. 18 storey building). Overall, from 10 to 22 storey building the maximum displacement in Y-direction has increased from $18.7 \mathrm{~mm}$ to $59.3 \mathrm{~mm}(68 \%$ increases from 10 to 22 storey building).

Therefore, rate of increase in displacements in either direction becomes slightly milder with increasing storey.

2) Storey drift:

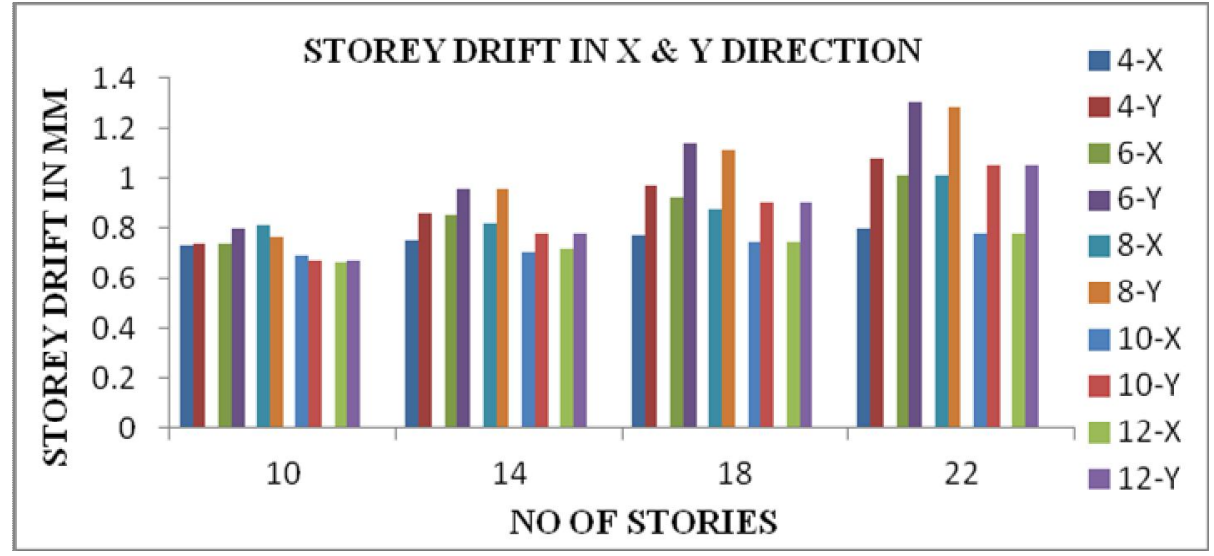

Figure 4.5 Storey Drift (in mm) in X \& Y-direction

Figure 4.5 shows variations in drift in both X \& Y-direction for case M3 for given number of shear walls varying from 4 to 12 numbers and for particular stories 10, 14, 18, 22.

For M3 combination with increasing no of shear walls, it is observed that minimum drift in $\mathrm{X}$ direction is $0.67 \mathrm{~mm}$ for 10 storey building which increases to $0.71 \mathrm{~mm}$ for 14 storey building ( $5 \%$ increase w.r.t. 10 storey building). Further for 18 storey building drift is increased to $0.75 \mathrm{~mm}$ (5\% increase w.r.t. 14 storey building) and then after increases to $0.77 \mathrm{~mm}$ for 22 storey building ( $2.6 \%$ increase w.r.t. 18 storey building). Overall, from 10 to 22 storey building the minimum drift in X-direction has increased from $0.67 \mathrm{~mm}$ to $0.77 \mathrm{~mm}$ (13\% increases from 10 to 22 storey building i.e. @ $1 \%$ increase in storey drift for each storey increase ).

The minimum drift in Y direction with increasing no of shear walls is observed to be $0.67 \mathrm{~mm}$ for 10 storey building which increases to $0.78 \mathrm{~mm}$ for 14 storey building (14\% increase w.r.t. 10 storey building). Further for 18 storey building drift is increased to $0.91 \mathrm{~mm}$ ( $14 \%$ increase w.r.t. 14 storey building) and then after increases to $1.05 \mathrm{~mm}$ for 22 storey building (14\% increase w.r.t. 18 storey building). Overall, from 10 to 22 storey building the minimum drift in Y-direction has increased from $0.67 \mathrm{~mm}$ to $1.05 \mathrm{~mm}$ (35.5\% increases from 10 to 22 storey building i.e. @ 3\% increase in storey drift for each storey increase).

The maximum drift in $\mathrm{X}$ direction with increasing no of shear walls is observed to be $0.81 \mathrm{~mm}$ for 10 storey building which increases to $0.85 \mathrm{~mm}$ for 14 storey building (5\% increase w.r.t. 10 storey building). Further for 18 storey building drift is increased to $0.93 \mathrm{~mm}$ (9\% increase w.r.t. 14 storey building) and then after increases to $1.01 \mathrm{~mm}$ for 22 storey building ( $8 \%$ increase w.r.t. 18 storey building). Overall, from 10 to 22 storey building the 
maximum drift in X-direction has increased from $0.81 \mathrm{~mm}$ to $1.01 \mathrm{~mm}$ (20\% increases from 10 to 22 storey building i.e. @ $1 \%$ increase in storey drift for each storey increase).

The maximum drift in Y direction with increasing no of shear walls is observed to be $0.8 \mathrm{~mm}$ for 10 storey building which increases to $0.96 \mathrm{~mm}$ for 14 storey building (17\% increase w.r.t. 10 storey building). Further for 18 storey building drift is increased to $1.14 \mathrm{~mm}$ (16\% increase w.r.t. 14 storey building) and then after increases to $1.33 \mathrm{~mm}$ for 22 storey building (14\% increase w.r.t. 18 storey building). Overall, from 10 to 22 storey building the maximum drift in Y-direction has increased from $0.8 \mathrm{~mm}$ to $1.33 \mathrm{~mm}$ (40\% increases from 10 to 22 storey building i.e. @ 3\% uniform increase in storey drift for each storey increase).

Therefore with increasing storey, rate of increase in storey drift in either direction is nearly linear.

3) Time period:

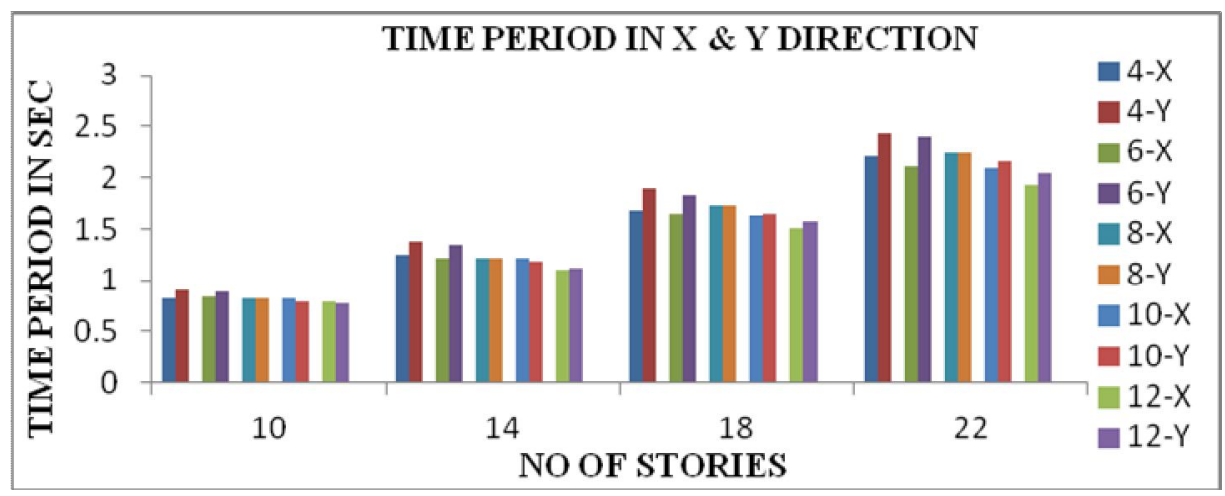

Figure 4.6Time period (in sec) in X \& Y-direction

Figure 4.6 shows variations in time period in both $\mathrm{X} \& \mathrm{Y}$-direction for case M3 for given number of shear walls varying from 4 to 12 numbers and for particular stories 10, 14, 18, 22.

For M3 combination with increasing no of shear walls, it is observed that that minimum time period in $\mathrm{X}$ direction is $0.76 \mathrm{sec}$ for 10 storey building which increases to $1.1 \mathrm{sec}$ for 14 storey building ( $31 \%$ increase w.r.t. 10 storey building). Further for 18 storey building time period is increased to $1.5 \mathrm{sec}(27 \%$ increase w.r.t. 14 storey building) and then after increases to $1.93 \mathrm{sec}$ for 22 storey building ( $22 \%$ increase w.r.t. 18 storey building). Overall, from 10 to 22 storey building the minimum time period in X-direction has increased from $0.76 \mathrm{sec}$ to $1.93 \mathrm{sec}(61 \%$ increases from 10 to 22 storey building \& its rate of increase becomes slightly milder with increasing storeys).

The minimum time period in Y direction with increasing no of shear walls is observed to be $0.77 \mathrm{sec}$ for 10 storey building which increases to $1.11 \mathrm{sec}$ for 14 storey building (30\% increase w.r.t. 10 storey building). Further for 18 storey building time period is increased to $1.58 \mathrm{sec}$ ( $30 \%$ increase w.r.t. 14 storey building) and then after increases to $2.05 \mathrm{sec}$ for 22 storey building ( $23 \%$ increase w.r.t. 18 storey building). Overall, from 10 to 22 storey building the minimum time period in Y-direction has increased from $0.77 \mathrm{sec}$ to $2.03 \mathrm{sec}$ (63\% increases from 10 to 22 storey building).

The maximum time period in $\mathrm{X}$ direction with increasing no of shear walls is observed to be $0.84 \mathrm{sec}$ for 10 storey building which increases to $1.24 \mathrm{sec}$ for 14 storey building (32\% increase w.r.t. 10 storey building). Further for 18 storey building time period is increased to $1.69 \mathrm{sec}$ ( $27 \%$ increase w.r.t. 14 storey building) and then after increases to $2.2 \mathrm{sec}$ for 22 storey building (23\% increase w.r.t. 18 storey building). Overall, from 10 to 22 storey building the maximum time period in X-direction has increased from $0.84 \mathrm{sec}$ to $2.2 \mathrm{sec}$ (62\% increases from 10 to 22 storey building).

The maximum time period in Y direction with increasing no of shear walls is observed to be $0.91 \mathrm{sec}$ for 10 storey building which increases to $1.38 \mathrm{sec}$ for 14 storey building (34\% increase w.r.t. 10 storey building). Further for 18 storey building time period is increased to $1.89 \mathrm{sec}$ ( $27 \%$ increase w.r.t. 14 storey building) and then after increases to $2.44 \mathrm{sec}$ for 22 storey building (22.5\% increase w.r.t. 18 storey building). Overall, from 10 to 22 storey building the maximum time period in Y-direction has increased from $0.91 \mathrm{sec}$ to $2.44 \mathrm{sec}$ (63\% increases from 10 to 22 storey building).

Therefore with increasing storey, rate of increase in time period in either direction becomes slightly milder. 


\section{CONCLUSION}

On the basis of various combinations, when shear walls are equally spaced in both direction, seismic performance is observed to be effective and for the best combination of shear walls and number of storey parametric study has been done. From the study and for L/B ratio 1.1, following are the conclusions.

5.1 When shear walls are provided only in one direction, structure becomes stiff in that direction and resists more lateral forces in that direction only. This will cause weakness in the other direction; therefore shear walls are recommended in both directions symmetrically located which will ensure overall safety and stability of the structure in both directions.

5.2 For building frame under consideration having L/B ratio 1.1, the improvement in the seismic performance is observed up to $25 \%$ of shear walls (up to 8 number of shear walls in the present study). However for shear walls beyond $25 \%$, not much significant improvement in seismic performance of the structure is observed.

5.3 Considering all above, for the buildings under consideration having L/B ratio 1.1, 25\% of shear walls are found to be optimum. These shear walls shall be placed symmetrically in X \& Y-direction (50-50\%).

Above conclusions are for building having L/B ratio 1.1 which are likely to vary with increase in L/B ratio. Therefore, in case L/B ratio changes separate study shall be carried out to investigate the effectiveness of shear wall.

\section{REFERENCES}

[1] Anuj Chandiwala, "Earthquake analysis of building configuration with different position of shear walls", International Journal of Emerging Technology and Advanced Engineering, ISSN 2250-2459, ISO 9001:2008 Certified Journal, Volume 2, Issue 12, 2012.

[2] C.V.R.Murty, "Earthquake Tip -Why are Buildings with Shear Walls preferred in Seismic Regions", Indian Institute of Technology Kanpur, India.

[3] C.V.R. Murty, Rupen Goswami, A. R. Vijayanarayanan, Vipul V. Mehta, "Some Concepts in Earthquake Behavior of Buildings", Gujarat State Disaster Management Authority Government of Gujarat.

[4] Dr. Halkude S.A., Kalyanshetti M.G., Tambake R.N., "Effect of Shear Wall in the Seismic Analysis of Building Frames Considering Soil Structure Interaction-A Study by Winklerian Approach", International Journal of Current Engineering and Technology,@2015 INPRESSCO Vol.5, No.5 (Oct 2015).

[5] K.Bhasker Rao, A.Kamal Tej, Md.Baseeruddin, B. Ravi Teja, B. Santhosh Reddy, "Project report on design and construction of shear walls", JNTU, HYD, civil engineering, gokarajurangaraju institute of engineering \& technology, Bachupally, Hyderabad.

[6] K.LovaRaju, Dr.K.V.G.D.Balaji, "Effective location of shear wall on performance of building frame subjected to earthquake load", International Advanced Research Journal in Science, Engineering and Technology, Vol. 2, Issue $1,2015$.

[7] K.V. Vijayendra, "Earthquake resistant design of structures (Subject Code: 06CV834) unit 5 \& unit 6: Seismic lateral force analysis", Department of Civil Engineering, BIT, Bangalore.

[8] Lakshmi k.o., Prof. Jayasree Ramanujan, Mrs. Bindu Sunil, Dr. Laju Kottallil, Prof. Mercy Joseph Poweth, "Effect of shear wall location in buildings subjected to seismic loads" ISOI journal of engineering and computer science, Volume 1, Issue 1, 2014.

[9] O. Esmaili1 S. Epackachiz M. Samadzad3 and S.R. Mirghaderi, "Study of Structural RC Shear Wall System in a 56-Story RC Tall Building", The $14^{\text {th }}$ World Conference on Earthquake Engineering October 12-17, 2008, Beijing, China. 
[10] P. P. Chandurkar, Dr. P. S. Pajgade, "Seismic Analysis of RCC Building with and Without Shear Wall", International Journal of Modern Engineering Research (IJMER) www.ijmer.com Vol. 3, Issue. 3, May - June 2013.

[11] P. Mary Williams, R. K. Tripathi, "Effect of Shear Wall Location on the Linear and Nonlinear Behavior of Eccentrically Loaded Buildings", Indian Journal of Science and Technology, Vol 9(22), June 2016.

[12] P. P. Chandurkar, Dr. P. S. Pajgade, "Seismic Analysis of RCC Building with and Without Shear Wall", International Journal of Modern Engineering Research (IJMER), Vol. 3, Issue. 3, May - June 2013.

[13] R.S.Mishra, V.Kushwaha, S.Kumar, "A Comparative Study of Different Configuration of Shear Wall Location in Soft Story Building Subjected to Seismic Load”, International Research Journal of Engineering and Technology (IRJET), Volume: 02 Issue: 07, 2015.

[14] R.S. Londhe, A.P. Chavan, "Behavior of building frames with steel plate shear walls", Asian journal of civil engineering (building and housing) vol. 11, no. 1 (2010).

[15] Suchita Tuppad, R.J.Fernandes, "Optimum location of shear wall in a multi-storey building subjected to seismic behavior using genetic algorithm”, international research journal of engineering and technology (IRJET), Volume: 02 issue: 04, 2015. 